\title{
TOLERANSI TANAMAN AKASIA (Acacia mangium Wild.) TERHADAP TINGKAT SALINITAS DI PEMBIBITAN
}

\section{(Tolerance of Acacia (Acacia mangium Wild.) to Level of Salinity in the Nursery) \\ Elfarisna, Hermawan Niaga dan Rita Tri Puspitasari}

Fakultas Pertanian Universitas Muhammadiyah Jakarta

Jl.K.H.A.Dahlan Cireundeu Ciputat Jakarta Selatan 15419

e-mail : elfa.risna@yahoo.com

\begin{abstract}
Acacia is a plant that can be used as the main ingredient of paper making. The potential of acacia wood pulp as the raw material is already widely recognized by the timber industry. Acacia also has potential as a plant greenery in urban areas. Production of acacia plants can be done through the efforts of agricultural extension. Enterprises agricultural extension can be done by expanding the agricultural frontier acacia plants in saline land. The purpose of the study to know acacia plant tolerance to salinity levels in the nursery. The research was conducted from April to July 2013 in the experimental garden of the Faculty of Agriculture, University of Muhammadiyah Jakarta. The research is used Randomized Complete Block Design (RCBD) with five treatments $\mathrm{NaCl}$ level concentration, ie P1 Without NaCl/Control, P2 (0.5\% concentration) P3 (concentration of 1\%), P4 (1.5\% concentration) and P5 (concentration of 2\%). Parameters measured were percentage growth, plant height, leaf number, stem diameter, plant fresh weight and dry weight of plants. The results showed salinity level significantly affected all parameters observed. A salt concentration of $1 \%$ is the maximum saline tolerance conditions for growth acacia.
\end{abstract}

Keywords : tolerance, acasia, salinity, nursery

\begin{abstract}
Abstrak
Akasia merupakan salah satu tanaman yang dapat dijadikan sebagai bahan utama pembuatan kertas. Potensi kayu akasia sebagai bahan baku pulp sudah diakui secara luas oleh perindustrian kayu. Akasia juga berpotensi sebagai tanaman penghijauan di perkotaan. Produksi tanaman akasia dapat dilakukan melalui usaha ekstensifikasi pertanian. Usaha ekstensifikasi pertanian dapat dilakukan dengan memperluas areal pertanian tanaman akasia pada lahan salin. Tujuan dari penelitian adalah untuk mengetahui toleransi tanaman akasia terhadap tingkat salinitas di pembibitan. Penelitian dilaksanakan dari bulan April sampai Juli 2013 di kebun percobaan Fakultas Pertanian Universitas Muhammadiyah Jakarta. Rancangan yang digunakan dalam penelitian ini adalah Rancangan Kelompok Lengkap Teracak (RKLT) dengan 5 perlakuan tingkat konsentrasi $\mathrm{NaCl}$, yaitu $\mathrm{P} 1 \mathrm{Tanpa} \mathrm{NaCl} / \mathrm{Kontrol}, \mathrm{P} 2$ (konsentrasi 0,5\%) P3 (konsentrasi 1\%), P4 (konsentrasi 1,5\%), dan P5 (konsentrasi 2\%). Parameter yang diamati adalah persentase tumbuh, tinggi tanaman, jumlah daun, diameter batang, bobot basah tanaman dan bobot kering tanaman. Hasil penelitian menunjukkan salinitas berpengaruh nyata terhadap semua parameter yang diamati. Konsentrasi garam 1\% merupakan kondisi toleransi salin maksimal untuk pertumbuhan tanaman akasia.
\end{abstract}

Kata kunci : toleransi, akasia, salinitas, pembibitan

\section{PENDAHULUAN}

Tanaman akasia (Acacia mangium Wild.)

termasuk jenis legum yang tumbuh cepat, dapat

tumbuh pada lahan tidak subur serta tidak begitu terpengaruh oleh jenis tanahnya.
Kayunya dapat dimanfaatkan sebagai bahan baku pulp dan kertas, serta sebagai bahan baku meubel. Kayu akasia dapat digunakan untuk kerangka pintu, bagian jendela dan bahan baku peti/kotak. Akasia yang berumur tujuh dan 
delapan tahun menghasilkan kayu yang dapat dibuat untuk papan partikel yang baik (Irwanto, 2007).

Produksi tanaman akasia dapat dilakukan melalui usaha intensifikasi pertanian dan usaha ekstensifikasi pertanian. Usaha intensifikasi pertanian dapat dilakukan dengan cara merakit varietas-varietas unggul yang mampu meningkatkan produksi per tahun. Sedangkan usaha ekstensifikasi pertanian dapat dilakukan dengan memperluas areal pertanian tanaman akasia. Meningkatkan lahan-lahan marginal dapat menjadi alternatif bagi para petani untuk menyiasati semakin berkurangnya lahan subur yang dapat digunakan. Salah satu lahan yang dapat dimanfaatkan adalah tanah yang memiliki kadar salinitas yang cukup tinggi. Sunarto (1997) melakukan penelitian pada varietas kedelai yang toleran terhadap salinitas atau mengadaptasikan varietas-varietas unggul yang sudah ada pada kondisi salin.

Cekaman salinitas mempengaruhi pertumbuhan tanaman dalam dua cara yaitu melalui peningkatan ion di sekitar akar dan akumulasi $\mathrm{Na}^{+}$dalam sel dan jaringan. Peningkatan konsentrasi ion di sekitar akar akan meningkatkan tekanan osmotic sehingga menghambat penyerapan air oleh akar, sedangkan akumulasi $\mathrm{Na}^{+}$dalam sel mengakibatkan kematian sel dan jaringan. Pengaruh peningkatan tekanan osmotic akan terlihat pada pertumbuhan dan perkembangan daun karena terganggunya pemanjangan dan pembelahan sel, sedangkan pengaruh toksisitas
$\mathrm{Na}^{+}$terlihat jelas pada peningkatan jumlah daun yang layu (Munns dan Tester, 2008).

Tanah salin adalah tanah yang mengandung garam $\mathrm{NaCl}$ Terlarut dalam jumlah banyak sehingga mengganggu pertumbuhan tanaman. Larutan garam tanah biasanya tersusun dari ion $\mathrm{Na}^{+}, \mathrm{Ca}^{2+}, \mathrm{Mg}^{2+}, \mathrm{Cl}^{-}$, $\mathrm{CO}^{2-}$, dan $\mathrm{Co}^{3-}$ (Sunarto, 1997). Menurut Soepardi (1979) kelebihan atau akumulasi garam dapat terjadi melalui: 1) evaporasi yang tinggi dibeberapa daerah seperti rawa dan daerah pasang surut, 2) intrusi air laut melalui sungai yang sering terjadi di daerah muara sebagai akibat naik turunnya air laut karena peristiwa pasang surut.

Kadar salinitas air laut di seluruh wilayah perairan di dunia berkisar antara 33-37\%, namun di laut merah mencapai 40\% (Eka, 2005). Berdasarkan hasil penelitian terhadap tanaman kacang panjang bahwa tingkat salinitas $1 \%$ merupakan titik cekam salinitas, sehingga dapat digunakan sebagai acuan tingkat salinitas tertinggi yang dapat diterima tanaman dalam famili legum (Novita, 2008). Berdasarkan hal tersebut dilakukan penelitian mengenai tingkat salinitas terhadap pertumbuhan akasia di pembibitan. Tujuan penelitian adalah untuk mengetahui toleransi tanaman akasia terhadap tingkat salinitas di pembibitan.

\section{METODOLOGI}

Penelitian dilaksanakan dari bulan April sampai bulan Juli 2013, di kebun percobaan Fakultas Pertanian Universitas Muhammadiyah Jakarta, dengan ketinggian 25 meter di atas 
permukaan laut (mdpl), dan jenis tanah Latosol. Penelitian menggunakan Rancangan Acak Kelompok (RAK) dengan perlakuan konsentrasi kadar garam $\mathrm{NaCl}$ sebagai berikut : P1 (tanpa NaCl/kontrol), P2 (konsentrasi $\mathrm{NaCl}$ $0,5 \%=5 \mathrm{~g} /$ liter air), $\mathrm{P} 3$ (konsentrasi $\mathrm{NaCl} 1 \%$ $=10 \mathrm{~g} /$ liter air), $\mathrm{P} 4$ (konsentrasi $\mathrm{NaCl} 1,5 \%=$ $15 \mathrm{~g} /$ liter air), dan P5 (konsentrasi $\mathrm{NaCl} 2 \%=$ $20 \mathrm{~g} /$ liter air). Setiap perlakuan diulang sebanyak empat kali dan setiap satuan percobaan terdiri dari sepuluh tanaman sehingga terdapat 200 tanaman yang diteliti.

Media tanam yang digunakan terdiri dari tanah, pasir, dan pupuk kandang dengan perbandingan 1:1:1. Media yang telah disiapkan kemudian dimasukan ke dalam polibag ukuran $7 \mathrm{x} 15 \mathrm{~cm}$. Kemudian diberi pupuk multicote sebanyak $3 \mathrm{~g}$ per polibag pada permukaan media. Benih yang akan digunakan terlebih dahulu diseleksi dan direndam dalam air hangat selama 10-15 menit. Benih Akasia ditanam tiga benih per polibag setelah tumbuh kemudian dipilih satu bibit dengan kondisi yang paling baik. Pada umur 3 minggu setelah tanam (MST) diberi perlakuan sesuai dengan konsentrasi $\mathrm{NaCl}$ (garam) masing-masing perlakuan sampai akhir penelitian, dengan dosis $40 \mathrm{ml}$ per tanaman (Hanri, 2003). Parameter yang diamati adalah : Persentase tumbuh diamati setiap 2 minggu sekali, yaitu pada umur 4, 6, 8, 10, dan 12 MST. Tinggi tanaman dan jumlah daun diamati setiap 2 minggu sekali, yaitu pada umur 4, 6, 8, 10, dan 12 MST. Diameter batang, bobot basah dan bobot kering diamati pada umur 12 MST. Untuk bobot kering, tanaman dioven pada suhu $70^{\circ} \mathrm{C}$ selama 24 jam.

\section{HASIL DAN PEMBAHASAN}

\section{Hasil Pengamatan \\ Persentase Tumbuh}

Hujan deras yang disertai angin kencang mengakibatkan beberapa tanaman rusak. Tanaman yang rusak pada perlakuan konsentasi garam $0,5 \%, 1 \%$ dan $1,5 \%$ pada ulangan satu pada umur 4 MST. Gangguan hujan tersebut menyebabkan tanaman mati pada perlakuan konsentrasi $0 \%$ (7,5\%), konsentrasi 0,5\% (7,5 $\%)$, dan konsentrasi $1 \%$ (2,5\%). Pengaruh perlakuan baru terlihat pada umur 6 MST dengan matinya tanaman pada semua perlakuan terutama yang konsentrasi $2 \%$ yang hidup cuma $2,5 \%$. Pemberian konsentrasi $\mathrm{NaCl} 2 \%$ menyebabkan semua tanaman mati pada umur 8 MST dan konsentrasi $\mathrm{NaCl}$ 1,5\% menyebabkan semua tanaman mati pada umur 10 MST. Pada minggu terakhir pengamatan 12 MST persentase tumbuh tertinggi ditunjukan oleh pemberian konsentrasi $\mathrm{NaCl} 0 \%(87,50 \%)$ dan persentase tumbuh terendah ditunjukkan oleh pemberian konsentrasi $\mathrm{NaCl} \quad 1 \% \quad(14,00 \%)$ (Tabel 1).

Penelitian tingkat toleransi salinitas pada pembibitan akasia menunjukkan bahwa tingkat salinitas $1 \%$ merupakan konsentrasi tertinggi untuk tumbuhnya bibit akasia. Persentase tumbuh pada konsentrasi tersebut hanya sebesar 14\%. Penurunan persentase tumbuh mulai terjadi dari umur 6 MST dan mencapai 
Tabel 1. Pengaruh konsentrasi garam terhadap persentase tumbuh bibit akasia

\begin{tabular}{lccccc}
\hline \multirow{2}{*}{ Perlakuan } & \multicolumn{5}{c}{ Persentase Tumbuh (\%) } \\
\cline { 2 - 6 } & 4 MST & 6 MST & 8 MST & 10 MST & 12 MST \\
\hline Tanpa NaCl/kontrol & 92,50 & 90,00 & 87,50 & 87,50 & 87,50 \\
Konsentrasi $\mathrm{NaCl} \mathrm{0,5 \%}$ & 92,50 & 67,50 & 52,50 & 42,50 & 40,00 \\
Konsentrasi $\mathrm{NaCl} \mathrm{1 \%}$ & 97,50 & 50,00 & 42,50 & 27,50 & 14,00 \\
Konsentrasi $\mathrm{NaCl} \mathrm{1,5 \%}$ & 100,00 & 10,00 & 2,50 & - & - \\
Konsentrasi $\mathrm{NaCl}$ 2\% & 100,00 & 2,50 & - & - & - \\
\hline
\end{tabular}

kematian pada bibit pada tingkat salinitas $2 \%$ di umur 8 MST. Kematian bibit disusul oleh bibit pada tingkat salinitas $1,5 \%$ pada umur 10 MST. Penurunan persentase tumbuh yang terjadi diduga disebabkan karena adanya cekaman salinitas terhadap bibit akasia. Cekaman salinitas mempengaruhi pertumbuhan tanaman dalam dua cara yaitu melalui peningkatan ion di sekitar akar dan akumulasi $\mathrm{Na}^{+}$dalam sel dan jaringan. Peningkatan konsentrasi ion di sekitar akar akan meningkatkan tekanan osmotik sehingga menghambat penyerapan air oleh akar, sedangkan akumulasi $\mathrm{Na}^{+}$dalam sel mengakibatkan kematian sel dan jaringan. Pengaruh peningkatan tekanan osmotik akan terlihat pada pertumbuhan dan perkembangan daun karena terganggunya pemanjangan dan pembelahan sel, sedangkan pengaruh toksisitas $\mathrm{Na}^{+}$terlihat jelas pada peningkatan jumlah daun yang layu (Munns dan Tester, 2008).

\section{Tinggi Tanaman}

Hasil analisis ragam menunjukkan perlakuan konsentrasi garam tidak berpengaruh nyata terhadap parameter tinggi tanaman akasia pada umur 4 MST tetapi berpengaruh sangat nyata pada umur 6 sampai 12 MST. Pada Tabel 2 memperlihatkan pada umur 6-10 MST, tanpa pemberian garam menghasilkan tanaman tertinggi tetapi tidak berbeda nyata dengan konsentrasi garam $0,5 \%$ dan $1 \%$. Pada umur 12 MST konsentasi garam 0,5\% $(13,61 \mathrm{~cm})$ tidak berbeda nyata dengan kontrol $(14,84 \mathrm{~cm})$.

Akasia merupakan tanaman yang sensitif terhadap kondisi salin. Pada tanaman yang sensitif terhadap garam pertumbuhan sudah terhenti ketika tingkat salintas rendah, hal ini mula-mula disebabkan oleh keracunan $\mathrm{Na}^{+}$dan $\mathrm{Cl}^{-}$. Tekanan osmotik yang tinggi pada senyawa tanah menyebabkan hubungan potensial air tanah rendah dan ketika terjadi kontak dengan sel tanaman terjadi pergerakan senyawa, ke arah persenyawaan tanah dan sel menjadi berkerut (plasmolisis) (Tisdale et al. 1993).

Cekaman salinitas menekan proses pertumbuhan tanaman dengan efek yang menghambat pembesaran dan pembelahan sel, produksi protein serta penambahan biomasa tanaman. Hasil penelitian yang dilakukan, ratarata tinggi bibit pada tingkat salinitas $1 \%$ pada umur 12 MST adalah $1,83 \mathrm{~cm}$ berbeda nyata dengan bibit yang normal yaitu $14,84 \mathrm{~cm}$. Tanaman yang mengalami stres garam umumnya tidak menunjukkan respon dalam 
bentuk kerusakan langsung tetapi pertumbuhan yang tertekan dan perubahan secara perlahan. Tanaman yang mampu memanfaatkan akumulasi $\mathrm{Na}^{+}$dalam jaringan, umumnya memiliki tinggi tanaman yang lebih pendek (Rahayu dan Harjoso, 2010) dan luas daun yang lebih kecil selama pembibitan (Sulyastini dan Mufriah, 2013).

\section{Jumlah Daun}

Perlakuan konsentrasi garam tidak berpengaruh nyata terhadap parameter jumlah daun tanaman akasia pada umur 4 MST tetapi berpengaruh nyata pada umur 6 dan berpengaruh sangat nyata dari umur 8 sampai 12 MST. Pada Tabel 3 perlakuan tanpa garam pada umur 6 MST (5,30 helai) memiliki daun terbanyak tetapi tidak berbeda nyata dengan konsentrasi $0,5 \%(5,23$ helai) dan konsentrasi $1 \%$ (4,51 helai). Pada umur 8 MST, Kontrol (6,65 helai) memiliki daun terbanyak tetapi tidak berbeda nyata dengan konsntrasi $0,5 \%$ (6,41 helai). Pada umur 10 MST, Konsentrasi $0,5 \%$ (7,75 helai) memiliki daun terbanyak tetapi tidak berbeda nyata dengan Kontrol (7,62 helai). Pada umur 12 MST, perlakuan tanpa garam (9,14 helai) memiliki daun terbanyak tetapi tidak berbeda nyata dengan konsentrasi $0,5 \%$ (8,53 helai) dan konsentrasi $1 \%(6,41$ helai).

Cekaman salinitas membuat daun akasia menjadi pucat kekuningan dan mengering. Penurunan jumlah daun yang terjadi saat penelitian dengan adanya peningkatan konsentrasi garam tidak terlalu banyak. Jumlah daun bibit pada tingkat salinitas $1 \%$ sebanyak
6,41 helai tidak berbeda nyata dengan bibit normal yaitu 9,14 helai. Gejala pertumbuhan tanaman pada tanah dengan tingkat salinitas yang cukup tinggi adalah pertumbuhan yang tidak normal seperti daun mengering di bagian ujung dan gejala khlorosis. Gejala ini timbul karena konsentrasi garam terlarut yang tinggi menyebabkan menurunnya potensial larutan tanah sehingga tanaman kekurangan air. Sifat fisik tanah juga terpengaruh antara lain bentuk struktur, daya pegang air dan permeabilitas tanah. Pertumbuhan sel tanaman pada tanah salin memperlihatkan struktur yang tidak normal. Penyimpangan yang terjadi meliputi kehilangan integritas membran, kerusakan lamella, kekacauan organel sel, dan akumulasi Kalsium Oksalat dalam sitoplasma, vakuola, dinding sel dan ruang antar sel. Kerusakan struktur ini akan mengganggu transportasi air dan mineral hara dalam jaringan tanaman (Sipayung, 2006).

Untuk mengatasi gejala kekurangan daun tanaman memiliki mekanisme toleransi dengan menutup stomata yang banyak terdapat pada daun. Oleh karena itu terjadi pengurangan jumlah daun sebagai salah satu mekanisme toleransi oleh tanaman. Mekanisme toleransi pada tanaman sebagai respons adanya cekaman kekeringan meliputi, kemampuan tanaman tetap tumbuh pada kondisi kekeringan air yaitu dengan menurunkan luas daun dan memperpendek siklus tumbuh, kemampuan akar untuk menyerap air di lapisan tanah paling dalam, kemampuan untuk melindungi meristem akar dari kekeringan dengan meningkatkan 
Tabel 2. Pengaruh konsentrasi garam terhadap tinggi tanaman bibit akasia.

\begin{tabular}{lccccc}
\hline \multirow{2}{*}{\multicolumn{1}{c}{ Perlakuan }} & \multicolumn{5}{c}{ Tinggi Tanaman $(\mathrm{cm})$} \\
\cline { 2 - 6 } & $4 \mathrm{MST}$ & $6 \mathrm{MST}$ & $8 \mathrm{MST}$ & $10 \mathrm{MST}$ & $12 \mathrm{MST}$ \\
\hline Tanpa $\mathrm{NaCl} / \mathrm{Kontrol}$ & $3,50 \mathrm{a}$ & $5,31 \mathrm{a}$ & $7,62 \mathrm{a}$ & $11,42 \mathrm{a}$ & $14,84 \mathrm{a}$ \\
Konsentrasi $\mathrm{NaCl} 0,5 \%$ & $3,10 \mathrm{a}$ & $4,12 \mathrm{a}$ & $5,53 \mathrm{a}$ & $8,23 \mathrm{a}$ & $13,61 \mathrm{a}$ \\
Konsentrasi $\mathrm{NaCl} \mathrm{1 \%}$ & $2,92 \mathrm{a}$ & $3,89 \mathrm{a}$ & $5,52 \mathrm{a}$ & $1,68 \mathrm{~b}$ & $1,83 \mathrm{~b}$ \\
Konsentrasi $\mathrm{NaCl} \mathrm{1,5 \%}$ & $2,75 \mathrm{a}$ & $1,83 \mathrm{~b}$ & $1,50 \mathrm{~b}$ & - & - \\
Konsentrasi $\mathrm{NaCl} 2 \%$ & $2,53 \mathrm{a}$ & $1,12 \mathrm{c}$ & - & - & - \\
\hline
\end{tabular}

Keterangan: Angka yang diikuti huruf yang sama pada kolom yang sama menunjukkan hasil yang tidak berbeda nyata berdasarkan DMRT pada $\alpha=5 \%$

Tabel 3. Pengaruh konsentrasi garam terhadap jumlah daun bibit akasia

\begin{tabular}{lccccc}
\hline \multicolumn{1}{c}{ Perlakuan } & \multicolumn{5}{c}{ Jumlah Daun (helai) } \\
\cline { 2 - 6 } & 4 MST & 6 MST & MST & MST & $12 \mathrm{MST}$ \\
\hline Tanpa $\mathrm{NaCl} /$ Kontrol & $3,50 \mathrm{a}$ & $5,30 \mathrm{a}$ & $6,65 \mathrm{a}$ & $7,62 \mathrm{a}$ & $9,14 \mathrm{a}$ \\
Konsentrasi $\mathrm{NaCl} 0,5 \%$ & $2,45 \mathrm{a}$ & $5,23 \mathrm{a}$ & $6,41 \mathrm{a}$ & $7,75 \mathrm{a}$ & $8,53 \mathrm{a}$ \\
Konsentrasi $\mathrm{NaCl} \mathrm{1 \%}$ & $2,22 \mathrm{~b}$ & $4,51 \mathrm{a}$ & $5,08 \mathrm{~b}$ & $4,75 \mathrm{~b}$ & $6,41 \mathrm{a}$ \\
Konsentrasi $\mathrm{NaCl} \mathrm{1,5 \%}$ & $2,15 \mathrm{~b}$ & $1,50 \mathrm{~b}$ & $0,75 \mathrm{c}$ & - & - \\
Konsentrasi $\mathrm{NaCl} 2 \%$ & $1,95 \mathrm{~b}$ & $1,00 \mathrm{~b}$ & - & - & - \\
\hline
\end{tabular}

Keterangan: Angka yang diikuti huruf yang sama pada kolom yang sama menunjukkan hasil yang tidak berbedanyata berdasarkan DMRT pada $\alpha=5 \%$

akumulasi senyawa tertentu seperti glisin, betain, gula alkohol atau prolin untuk osmotik adjustment dan mengoptimalkan peranan stomata untuk mencegah hilangnya air melalui daun (Nguyen, Babu,dan Blum, 1997). Stomata berperan penting sebagai alat untuk adaptasi tanaman terhadap cekaman kekeringan. Pada kondisi cekam kekeringan akan menutup sebagai upaya untuk menahan laju transpirasi (Pugnaire dan Pardos, 1999). Kemampuan mengurangi jumlah stomata ini di tentukan oleh pengaruh lingkungan dalam menentukan jumlah stomata persatuan luas. Menebalnya lapisan kutikula juga merupakan salah satu strategi tanaman untuk mengurangi kehilangan air dalam jaringan akibat transpirasi.

\section{Diameter Batang}

Perlakuan konsentrasi garam berpengaruh sangat nyata terhadap diameter batang tanaman akasia pada umur 12 MST. Pada Tabel 4 memperlihatkan perlakuan kontrol $(0,17 \mathrm{~cm})$ memiliki diameter yang paling besar tetapi tidak berbeda nyata dengan konsentrasi $0,5 \%(0,16 \mathrm{~cm})$ dan perlakuan konsentrasi $1 \%$ $(0,10 \mathrm{~cm})$.

Penurunan kapasitas air oleh tanaman (kekeringan fisiologi tanaman), toksisitas $\mathrm{Na}$ danCl yang berlebihan, ketidakseimbangan penyerapan unsur hara, perubahan dan penyimpangan bentuk dan anatomi daun serta terganggunya proses fisiologi tanaman terutama fotosintesis (Parida dan Das, 2005). 
Tabel 4. Pengaruh konsentrasi garam terhadap diameter batang bibit akasia

\begin{tabular}{lc}
\hline \multicolumn{1}{c}{ Perlakuan } & Diameter Batang (cm) \\
\hline Konsentrasi $\mathrm{NaCl} \mathrm{0 \%}$ & $0,17 \mathrm{a}$ \\
Konsentrasi $\mathrm{NaCl} 0,5 \%$ & $0,16 \mathrm{a}$ \\
Konsentrasi $\mathrm{NaCl} 1 \%$ & $0,10 \mathrm{a}$ \\
Konsentrasi $\mathrm{NaCl} 1,5 \%$ & - \\
Konsentrasi $\mathrm{NaCl} 2 \%$ & - \\
\hline
\end{tabular}

Keterangan: Angka yang diikuti huruf yang sama pada kolom yang sama menunjukkan hasil yang tidak berbeda nyata berdasarkan DMRT pada $\alpha=5 \%$

Tabel 5. Pengaruh konsentrasi garam terhadap bobot basah dan bobot kering bibit akasia

\begin{tabular}{lcc}
\hline \multicolumn{1}{c}{ Perlakuan } & Bobot Basah $(\mathbf{g})$ & Bobot Kering $(\mathbf{g})$ \\
\hline Tanpa $\mathrm{NaCl} / \mathrm{Kontrol}$ & $2,56 \mathrm{a}$ & $0,71 \mathrm{a}$ \\
Konsentrasi $\mathrm{NaCl} 0,5 \%$ & $2,48 \mathrm{a}$ & $0,66 \mathrm{a}$ \\
Konsentrasi $\mathrm{NaCl} \mathrm{1 \%}$ & $0,72 \mathrm{~b}$ & $0,17 \mathrm{~b}$ \\
Konsentrasi $\mathrm{NaCl} \mathrm{1,5 \%}$ & - & - \\
Konsentrasi $\mathrm{NaCl} 2 \%$ & - & - \\
\hline
\end{tabular}

Keterangan : Angka yang diikuti huruf yang sama pada kolom yang sama menunjukkan hasil yang tidak berbeda nyata berdasarkan DMRT pada $\alpha=5 \%$

Penyimpangan bentuk tersebut menyebabkan penurunan ukuran diameter batang bibit akasia. Rosmarkam dan Yuwono (2002) mengatakan bahwa pengaruh garam terhadap pertumbuhan tanaman dipengaruhi oleh : kadar garam diambang batas toleransi, peningkatan kadar garam berpengaruh semakin jelek bagi tanaman.

\section{Bobot Basah dan Bobot Kering Tanaman}

Umur 12 MST menunjukkan bahwa perlakuan konsentrasi garam berpengaruh sangat nyata terhadap bobot basah dan bobot kering tanaman akasia. Tabel 5, pada umur 12 MST bobot basah paling berat dihasilkan oleh perlakuan tanpa garam (2,56 gram) tetapi tidak berbeda nyata dengan konsentrasi garam $0,5 \%$ (2,48 gram) dan konsentrasi garam $1 \%(0,72$ gram). Pengamatan bobot kering paling berat pada umur 12 MST dihasilkan oleh perlakuan tanpa garam $(0,71$ gram $)$ berbeda nyata dengan konsentrasi $1 \%$ (0,66 gram).

Berat basah dan berat kering bibit akasia berhubungan dengan kandungan air dalam tanaman. Air terdapat dalam jaringan tanaman. Pertumbuhan yang terhambat menyebabkan jaringan tidak berkembang. Tanaman yang toleran terhadap salinitas harus mampu menyesuaikan terhadap stres osmotik. Seperti telah dinyatakan tanaman bahwa tanaman dapat menyesuaikan dengan menurunkan potensial osmosis tanpa kehilangan turgor, kecuali proses salinitas terjadi secara tiba-tiba. Penyesuaian kira-kira 1 bar/hari telah pernah diamati, tetapi laju dan lamanya tergantung kepada spesies 
tanaman. Pada kondisi lapangan secara normal, laju penyesuaian ini cukup untuk mengadapi perubahan salinitas secara bertahap (gradual). Di samping umumnya pertumbuhan yang tertekan, salinitas menyebabkan beberapa perubahan stuktur yang khas yang nyata-nyata memperbaiki keseimbangan air tanaman. Keseimbangan air tanaman secara sederhana, berarti bahwa potensial air dalam tanaman cukup untuk pertumbuhan dan aktivitas yang normal. Hal ini mencakup pengaturan pengambilan air, hilangnya dan distribusinya dalam tanaman (Siregar, Rosmayati dan Julita, 2010). Tetapi menyebabkan tanaman terhambat dalam proses pembentukkan dan pertumbuhan akarnya terhambat, akar menjadi lebih sedikit, kurus dan kecil, akar menggulung dengan rambut akar yang sedikit dan warna akar cenderung kuning kecoklatan. Akar tumbuhan berfungsi untuk memperkuat berdirinya tubuh tumbuhan, menyerap air dan unsur hara tumbuhan dari dalam tanah, mengangkut air dan unsur hara ke bagian tumbuhan yang memerlukan, dan kadang kala sebagai tempat pertumbuhan zat makanan cadangan (Nugroho, Purnomo dan Sumardi, 2006).

Berkurangnya panjang akar pada media salin diduga juga akibat daya racun $\mathrm{Cl}$, ketidakseimbangan unsur di dalam tanaman serta adanya akumulasi $\mathrm{NaCl}$ di sekitar akar dan di dalam akar. Sehingga dapat dimengerti, pada konsentrasi $\mathrm{NaCl}$ tinggi, pertumbuhan daun juga kecil, menggulung dan tidak berkembang sempurna (Siregar,Rosmayati dan Julita, 2010).

\section{SIMPULAN}

Berdasarkan hasil penelitian yang diperoleh dapat disimpulkan bahwa :

1. Tingkat salinitas berpengaruh nyata terhadap semua parameter yang diamati.

2. Konsentrasi garam $1 \%$ merupakan kondisi toleransi salin maksimal untuk pertumbuhan tanaman akasia.

\section{DAFTAR PUSTAKA}

Eka, Djunarsjah. 2005. Sifat-sifat Fisik Air Laut.http://sudomogis.com/Tulisan/Hidro grafi-sifat-Fisik-Air-Laut.pdf [diakses 19 Maret2013].

Hanri, N. 2003. Respon Pertumbuhan Semai Acacia mangium Willd. Pada Tanah Podsolik Merah Kuning dengan Kondisi Ketersediaan Air yang Berbeda.Forest Management.IPB. Bogor.

Irwanto. 2007. Budidaya Tanaman Kehutanan.http://www.irwantoshut.com [diakses 10 Maret 2013].

Munns, R., M. Tester. 2008. Mechanism and Salinity Tolerance. Annual Review of Plant Biology. 59. Hal. 651-681.

Nguyen, Ht., R.C. Babu, dan A. Blum. 1997. Breeding for Drought Resistance in Rice Physiology and Molecular. Genetic Considerative Crop Science 37. Hal. 1426-1434.

Novita. 2008. Pengaruh Invigorasi Benih untuk Memperbaiki Perkecambahan Kacang Panjang (Vigna sinensis L.) pada Cekaman Salinitas. Pemuliaan Tanaman dan Teknologi Benih, Fakultas Pertanian - IPB. Bogor.

Nugroho, L. H., Purnomo dan Issirep Sumardi. 2006. Struktur dan Perkembangan Tumbuhan. Penebar Swadaya. Bandung. 
Parida, A. K. dan Das, A. B. 2005. Salt Tolerance and Salinity Effects on Plants: a Review. Ecotoxicology and Environmental Safety, Vol. 60, Hal. 324349.

Pugnaire F. I, L. Serrano dan J. Pardos, 1999. Contains by Water Stress on Plant Growth In M. Pessarakli (Ed.). Handbook of Plant and Crop Sress. $2^{\text {nd }}$ Edition. New York: Marcell Dekker. Hal.271-283.

Rahayu, M. U. Soetrisna dan H. Sumiasri. 1991. Potensi Beberapa Jenis Acacia di Indonesia dalam Hutan Tanaman Industry. Jurnal Penelitian dan Pengembangan Kehutanan. Bogor.

Rosmarkam, A. dan N. Yuwono. 2002. Ilmu Kesuburan Tanah. Kanisius. Yogyakarta.

Sipayung, Rosita. 2006. Cekaman Garam. http://usu.ac.id/download/fp/bdprosita2.pdf [Diakses pada 25 November 2013].

Siregar, L. A. Mahmud, Rosmayati dan Julita. 2010. Uji Beberapa Varietas Tomat (Licopersicum esculentum Mill.) Terhadap Salinitas. Program Studi Agroekoteknologi, Fakultas Pertanian Universitas Sumatra Utara. Medan.

Suliastini, R., dan D. Mufriah. 2013. Peningkatan Produksi Padi (Oriza sativa L.) Melalui Adaptasi Morfologi, Anatomi dan Produksi pada Lahan Cekam Garam. Lokakarya Nasional dan Seminar Forum Komunikasi Perguruan Tinggi Pertanian Indonesia (FKPTPI). Bogor.

Sunarto. 1997. Varietas Unggul Selamet dan Sindoro. Fakultas Pertanian Universitas Jenderal Soedirman. Bandung.

Suwarno. 1985. Pewarisan dan Fisiologis Sifat Toleran Terhadap Salinitas pada Tanaman Padi. Disertasi Program Pasca Sarjana Institut Pertanian Bogor.
Tisdale, S. L., W. L. Nelson, J. D. Beaton and J. L. Havlin. 1993. Soil Fertility and Fertilizers. MacMillan Publishing Company, New York. 